\title{
International Law in Asia: A Bibliographic Survey - 2019
}

\author{
Sharad Sharma*
}

\section{Introduction}

This bibliography provides information on books, articles, notes, and other materials dealing with international law in Asia, broadly defined. Only English language publications that are newly published in 2019 or those that were previously published but had updated editions in 2019 are listed in this survey. Please refer to earlier editions of the Asian Yearbook of International Law for earlier bibliographies from earlier editions.

Most, if not all, of the materials, can be listed under multiple categories, but each item is listed under a single primary category. However, edited books may appear more than once if multiple chapters from the book are listed under different categories. Readers are advised to refer to all categories relevant to their research. The headings used in this year's bibliography are as follows:

1. General Theories and Asian Culture

2. Boundary Delimitation and Sovereignty

3. International Dispute Settlement

4. Arbitration

5. Development

6. Commercial Law

7. Economic and Business Law

8. Intellectual Property and Technology

9. Environmental Law

10. Human Rights

11. Migration and Refugees

12. International Humanitarian Law, Criminal Law, and Transnational Crime

13. Law of the Sea

14. Maritime Law

15. Watercourses

* Attorney (licensed in Washington, D.C., USA, and Nepal) and Ph.D. candidate, Handong Global University. 
16. Cyber Law and Security

17. Air \& Space and Nuclear

18. Miscellaneous

Walter C. Clemens Jr., Violence and Nonviolence in South Asia, 43(1) Asian Perspe CTIVE 209-214 (2019).

Ritwick Dutta, Reintroduction of the Asiatic Lion: Precedence of Politics over Rule of Law, Economic and Political Weekly (2019).

Khagesh Gautam, The Use of International Law in Constitutional Interpretation in the Supreme Court of India, 55(1) STANFORD Journal of INTERNATIONAL LAW 27 (2019).

Gustavo Gozzi, Transcivilizational International Law Against the System of International Relations: Onuma Yasuaki's Normative Choice, 9(1) Asian Journal of InTERnATIONAL LAW 170-176 (2019).

Vijay Kumar et al., Book Review - History and Theory of International Law - Is International Law International? by Anthea ROBERTS, 9(2) AsIAN Journal of INTERNATIONAL LAW 392 (2019).

Christina Maags \& Ioan Trifu, When East Meets West: International Change and Effects on Domestic Cultural Institutions, 47(2) Politics AND Policy 326-38o (2019).

Lauri Malksoo, Civilization Diversity as Challenge to the (False) Universality of International Law, 9(1) Asian Journal of InTERnATional LAW 155-164 (2019).

Florian Counveinhes \& Matsumoto, The End of History of Liberalism and the Last 'Transcivilizations' Man? Onuma's Attempt to Define a 'New' International Law 9(1) As IAN JoURNAL OF INTERNATIONAL LAW 185-193 (2019).

Satya Mouland, Rethinking Adjudicative Jurisdiction in International Law, 29(1) PACIFIC Rim Law And Policy Journal 173-206 (2019).

W. Michael Reisman \& Tomo B. Takaki, How Shall We Fashion International Legal Goals and Criteria for Appraisal in a World of Many Civilizations and Cultures? Review of Onuma Yasuaki's International Law in a Transcivilizational World, 9(1) AsIAN JouRNAL OF INTERNATIONAL LAW 177-184 (2019).

Eglantin Staunton \& Jason Ralph, The Responsibility to Protect Norm Clusters and the Challenge of Atrocity Prevention: An Analysis of European Union's Strategy in Myanmar, 26(3) European Journal of International Relations 66o686 (2019). 


\section{Boundary Delimitation and Sovereignty}

Sacha Bachmann \& Martinus Prazauskas, The Status of Unrecognized Quasi-States and Their Responsibilities Under the Montevideo Convention, 52(3) THE INTERNATIONAL LAWYER 393-437 (2019).

Natalie Klein, The Timor Sea Conciliation and Lessons for Northeast Asia in Resolving Maritime Boundary Disputes, 6(1) Journal of Territorial AND MARITIME Disputes 30-50 (2019).

Peter Kristensen, States of Emergence, States of Knowledge: A Comparative Sociology of International Relations in China and India, 25(3) EURopeAn JourNAL of INTERNATiONAL RELATIONS 772-799 (2019).

Tom Phuong Le, Negotiating in Good Faith: Overcoming Legitimacy Problems in the Japan-South Korea Reconciliation Process, 78(3) The Journal of Asian Studies 621-44 (2019).

Untalimile Mokoena \& E. Lubaale, Extradition in the Absence of State Agreements Provisions in International Treaties on Extradition, 2019(67) SA Crime QUARTERLY 31-42 (2019).

Priyasha Saksena, Jousting Over Jurisdiction: Sovereignty and International Law in Late Nineteenth-Century South Asia, 38(2) LAw AND History Review 409-457 (2019).

Mohammad Shahabuddin, Post-colonial Boundaries, International Law, and the Making of the Rohingya Crisis in Myanmar, 9(2) ASIAN JournaL OF INTERNATIONAL LAW 334-358 (2019).

Laura Southgate, Asean Resistance to Sovereignty Violation: Interests, Balancing and the Role of the Vanguard State (2019).

Katherine Hui-Yi Tseng, Protect the Unprotected: The Escaping North Korean Issue and China's Dual Dilemma of Theoretical Enlightenment and Operational Trial, 32(4) THE PACIFIC RevieW 505-536 (2019).

\section{$3 \quad$ International Dispute Settlement}

Eunice Chua, The Singapore Convention on Mediation - A Brighter Future for Asian Dispute Resolution, 9(2) Asian Journal of International LAW 195-205 (2019).

Md. Manjur Hasan \& He Jian, Spratly Island Dispute in the South China Sea: Potential Solution, 12(1) Journal of EAST Asia AND International LAW 145-168 (2019). Angela Semme Kim, An End to the Korean War: The Legal Character of the 2018 Summit Declarations and Implications of an Official Korean Peace Treaty, 9(2) AsIAN JourNAL OF INTERNATIONAL LAW 206-216 (2019). 
Tom Phuong Le, Negotiating in Good Faith: Overcoming Legitimacy Problems in the Japan-South Korea Reconciliation Process, 78(3) The Journal of Asian Studies 621-644 (2019).

Lanchan McNamee \& Anna Zhang, Demographic Engineering and International Conflict: From China and Former USSR, 73(2) International ORganization 291-327 (2019).

TV Paul, When Balance of Power Meets Globalization: China, India and The Small States of South Asia, 39(1) Politics (Manchester, England) 50-63 (2019).

Quayle et al., International Organizations and the Promotion of Effective Dispute Resolution, Аiı YeARbook of International LAW (2019).

Koichi Sato, The Senkaku Island Dispute: Four Reasons of the Chinese Offensive - A Japanese View, 8(1) Journal of Contemporary East Asia Studies 5o-82 (2019).

Trina Vithayathil et al., The Retreat to Method: The Aftermath of Elite Concession to Civil Society in India and Mexico, 54(1) STUdies In CoMparative INTERNATIONAL DEVELOPMENT 19-39 (2019).

4

Arbitration

Jason Ahniesszka, Price Reviews and Arbitrations in Arbitrations in Asian LNG Markets, OXFord Institute For ENERgy Studies (2019).

Chiann Bao, Hong Kong Courts: International Arbitration Law in the Making, 2 BELGian Review of Arbitration 615-628 (2019).

F.J.J. Espinella, Judicial Fact-Finding Initiatives in the South China Sea Arbitration, 9(1) Asian Journal of InTERnAtional LAW 20-30 (2019).

Nur Emma Mustaffa et al., Application of Direct Payment Clause 30 A.o of Asian International Arbitration Centre (AIAC), 6(1) International Journal of Built ENVIRONMENT AND Sustainability 44-50 (2019).

F.A. Olorundami, Should the Diaoyou/Senkaku Islands Be Classified as Islands or Rocks? An Examination in Light of the South China Sea Arbitration Award, 34(2) THE INTERNational Journal of Marine and Coastal LaW 325-349 (2019).

Weiyi Tan, Allowing the Exclusion of Set-aside Proceedings: An Innovative Means of Enhancing Singapore's Position as an Arbitration Hub., 15(2) Asian INTERNAtional Arbitration Journal 87-118 (2019).

Serafettin Yilmaz \& Fu Kuo Liu, The Evolving Geopolitical Landscape in the PostArbitration South China Sea, 34(3) The PACIFIC Focus 317-344 (2019).

Judy Li Zhu, Time to Loosen Up on Ad-Hoc Arbitration in China? 15(1) Asian AsiAn International Arbitration Journal 43-53 (2019). 


\section{$5 \quad$ Development}

John Draper \& Joel Sawat Selway, A New Dataset on Horizontal Structural Ethnic Inequalities in Thailand in Order to Address Sustainable Development Goal 10, 141(1) Social IndicATOR RESEARCH Social Indicators Research 275-97 (2019).

Liu Junxia, Investments in the Energy Sector of Central Asia: Corruption Risk and Policy Implications, 133(C) Elsevier Journal of Energy Policy (2019).

Nagesh Kumar \& Ojasvee Arora, Financing Sustainable Infrastructure Development in South Asia: The Case of AIIB, 10(4) Global Policy 619-24 (2019).

Debin Ma, Financial Revolution Republic of China During 1900-37: A Survey and New Interpretation, 59(3) Australian Economic History Review 242-262 (2019).

Helen E. S. Nesadurai, Transnational Private Governance as a Developmental Driver in Southeast Asia: The Case of Sustainable Palm Oil Standards in Indonesia and Malaysia, 55(9) The Journal of Development Studies 1892-9o8 (2019).

Saira Bano Orakzai, Pakistan's Approach to Countering Violent Extremism (CVE): Reframing the Policy Framework for Peacebuilding and Development Strategies, 42(8) Studies in Conflict ANd Terrorism 755-770 (2019).

Huaigao Qi, Joint Development in the South China Sea: China's Incentives and Policy Choices, 8(2) Journal of Contemporary East Asia Studies 220-239 (2019).

Abbas Rajabifard (Ed.), Sustainable Development Goals Connectivity Dilemma: LAND and Geospatial Information for Urban and RuRAL RESILIENCE (2019).

Bala Ramaswamy \& Matthew C.H. Yeung, China's One Belt One Road Initiative: The Impact of Trade Facilitation Versus Physical Infrastructure on Exports, 42(6) WORLD EсоNOMY 1673-1694 (2019).

Heng Wang, China's Approach to the Belt and Road Initiative; Scope, Character and Sustainability, 22(1) Journal of INTERnATIONAL ECONOMIC LAW 29-55 (2019).

Yongliang Yan, Maintaining Long-Term Sustainability of Outer Space Activities: Creation of Regulatory Framework to Guide the Asia-Pacific Space Cooperation Organization and Selected Legal Issues, 47 Elsevier Journal of Space Policy 51-62 (2019).

\section{Commercial Law}

Bashir Ahmed \& Mohammad Tarikul Islam, Bangladesh-Nepal Trade Relations: Understanding the Influence of Economic Diplomacy, 23(1) JADAVPUR JOURNAL OF INTERNATIONAL RELATIONS 105-19 (2019).

Randall Akee et al., Unintended Consequences of China's New Labor Contract Law on Unemployment and Welfare Loss of the Workers, 53 CHINA ECONOMIC REviEW $87-105$ (2019). 
Garth Jody Bouwers, Tacit Choice of Law in International Commercial Contracts - the Position in Indonesian, Malaysian and Singaporean Private International Law, The Comparative and International Law Journal of South Africa 52(1) 109-125 (2019).

Debashis Chakraborty et al., Is it Finally Time for India's Free Trade Agreements? The ASEAN 'Present' and the RCEP 'Future', 9(2) As IAN Journal of INTERNATIONAL LAW 259-391 (2019).

Sheetal Chhabria, Book Review - Ocean of Trade: South Asian Merchants, Africa and the Indian Ocean by Johan MACHADO, 30(1) JOURNAL OF WORLD History 17801950 (2019).

Yuji Genda et al., Employees Who Do Not Know Their Labour Contract Term and the Implications for Working Conditions: Evidence from Japanese and Spanish Microdata, 49 JAPAN AND THE World ECONOMY 95-104 (2019).

Fukunari Kimura, Defending the Rule-Based Trading Regime: The Multilateral Trading System at Risk and Required Responses, 18(3) Asian Economic PAPERS 78-87 (2019).

Kongzhong Liu \& Julien Chaisse, The Future of Asian Trade Deals and IP (2019).

Shuzhong Ma et al., Input Tariff Liberalisation and Servitization in Manufacturing: Evidence from China's WTO Accession, 42(12) WORLD EcoNOMY 3569-87 (2019).

Qilin Mao and Jiayun Xu, Input Trade Liberalization, Institutions and Markup: Evidence from China's Accession to the WTO, 42(12) WORLD ECONOMY 3537-68 (2019).

June Park \& Troy Stangarone, Trump's America First Policy in Global and Historical Perspectives: Implications for US-East Asian Trade, 43(1) Asian Perspective 1-34 (2019).

Richard Pomfret, The Central Asian Economies in the Twenty-First Century: Paving a New Silk Road (2019).

Robert S Ross, On the Fungibility of Economic Power: China's Economic Rise and the East Asian Security Order, 25(1) European Journal of International Relations 302-327 (2019).

Jaivir Singh et al., Factors Influencing the Decision to Hire Contract Labour by Indian Manufacturing Firms, 47(4) LANd Oxford Development Studies 406-19 (2019).

Chor Foon Tang \& Salah Abosedra, Logistics Performance, Exports, and Growth: Evidence from Asian Economies, 78 ELSEVIER JournAL of RESEARCH IN TrANSPORTATION ECONOMICS 100743 (2019).

Hans Tjio, Merrill and Smith's Intermediate Rights Lying Between Contract and Property: Are Singapore Trusts and Secured Transactions Drifting Away from English Law Towards American Law?, 19 Singapore Journal of Legal Studies 235-62 (2019). 
Fuxi Wang et al., China's Employment Contract Law: Does It Deliver Employment Security? 3o(1) The Economic and Labour Relations Review 99-119 (2019).

Liang Zhao, FOB Seller Under Chinese Law and Privity of Contract in Carriage of Goods by Sea, 27(2) Asia Pacific Law Review 286-305 (2019).

\section{Economic and Business Law}

Tim G. Andrew et al., Corruption in Asia Pacific Business Organizations: Insight on Causes, Conditions, Consequences and Treatment, 25(4) Asia PACIfiC Business REVIEW 459-469 (2019).

Woo-Joo Byun, Effects of CISG on the Principles of Asian Contracts Law, 27 Dong A Journal of International Business Transaction LAW 159-181 (2019).

Sea-Jin Chang, When to Go It Alone: Examining Post Conversion Performance of International Joint Ventures, 50 (6) Journal of International Business Studies 998-1020 (2019).

Maura Dykstra, Cross-Jurisdictional Trade and Contract Enforcement in Qing China, 16(2) Inte rnational Journal of Asian Studies 99-115 (2019).

Carlos Esplugues (Ed.), Foreign Investment and Investment ArbitraTION IN ASIA (2019).

Andrew Harding, Book Review - The Business of Transition: Law Reform Development and Economics in Myanmar by Melissa CROUCH, 41(1) CONTEM PORARY SOUTHEAST AsIA 144-146 (2019).

Eugenia Heldt \& Henning Schmidtke, Explaining Coherence in International Regime Complexes: How the World Bank Shapes the Field of MultilateralDevelopment Finance, 26(6) Review of International Political Economy 116o-1186 (2019).

Nur Imamh et al., Islamic Law, Corporate Governance, Growth Opportunities and Dividend Policy in Indonesia Stock Market, 55 Pacific-Basin Finance Journal 110-126 (2019).

Petr Janský \& M. Šedivý, Estimating the Revenue Costs of Tax Treaties in Developing Countries, 42(6) World ECONOMY 1828-1849 (2019).

Wei Jiang et al., Density of Local Cadres and Regional Economic Performance: Evidence from China, 42(9) WoRLD ECONOMY 2723-2744 (2019).

Michael Lang \& Jeffrey OWens (Eds.), Removing Tax Barriers to China's BELT AND RoAd Initiative (2019).

Kung-Chung Liu \& Uday S. Racherla (Eds.), Innovation, Economic Development, and Intellectual Property in India and China: ComPARING Six Economic Sectors (2019).

Junji Nakagawa, Asian Perspectives on International Investment Law (2019). 
Uddhab Prasad Pyakurel, The BRI, Nepal's Expectations, and Limitations on Nepal-China Border Relations, 55(3), Issues and Studies: A Social Science QuArterly on China, Taiwan and East Asian Studies (2019).

Arvin Kristopher A Razon, Cross Border Contracting for Consumer Software in the Philipinnes: Addressing Foreign Ownership Limitations and Consumer Protection Issues, 6(1) Journal of International and Comparative LaW 153-169 (2019).

Zabihollah Rezaee et al., Business Sustainability in Asia: Compliance, Performance, And Integrated Reporting And Assurance (2019).

Santanu Sarkar, How Independent is India's Labour Law Framework from the State's Changing Economic Policies?, 30(3) The Economic and Labor Relations REview 422-440 (2019).

Changyun Wang et al., Social Trust, Rule of Law, and Economic Exchange: Evidence from China and Its Major Trading Partners, 55(14) Emerging Markets Finance \& TRADE 3134-315o (2019).

Barbara Haris White \& Lucia Michelutti (eds.), The Wild East: Criminal Political Economies in South Asia (2019).

W. Van der Wolf et al. (Eds.), Philip Morris Asia limited (Hong Kong) v. Commonwealth of Australia (2019).

Liang Zhao, FOB Seller Under Chinese Law and Privity of Contract in Carriage of Goods by Sea, 27(2) Asia Pacific Law Review 286-305 (2019).

Weiyhan Zhou, China's Implementation of the Rulings of the World Trade Organization (2019).

\section{$8 \quad$ Intellectual Property and Technology}

Bob Carbaugh \& Chad Wassell, Forced Technology and China, 39(3) EConomic Affairs: An International Journal of Liberal Political Economy 306-319 (2019).

Zhiyuyan Chen \& Jei Zhang, Types of Patents and Driving Forces Behind the Patent Growth in China, 8o The International Journal of Theoretical and Applied Papers on Economic Modelling 294-302 (2019).

Qiaoling HE, The Limits to Law: How Intellectual Properties Are Used and Protected in Chinese Industries, 7 (2) As IAN Journal of LAW AND Society 369-402 (2019).

Christopher Heath \& Anselm Kamperman Sanders (Eds.), Intellectual Property and International Dispute Resolution (2019).

Christopher Heath \& Atsuhiro furuta (Eds.), Japanese Patent Law: Cases And Comments (2019).

David Jefferson \& Kamalesh Adhikari, Reimagining the Relationship Between Food Sovereignty and Intellectual Property for Plants: Lessons from Ecuador and Nepal, 22(5o6) The Journal of World Intellectual Property 396-418 (2019). 
Kung Chung liu \& Uday S. Racherla (Eds.), Innovation, Economic Development, and Intellectual Property in India And China (2019).

Lily Martinet, Traditional Cultural Expressions and International Intellectual Property Law, 47(1) International Journal of LEgal Information 6-12 (2019).

Julia Ya Qin, Forced Technology Transfer and the US-China Trade War: Implications for International Economic Law, 22(4) JoURnAL of INTERNATIONAL ECONOMIC LAW 743-762 (2019).

Seemantani Sharma, RCEP and Trans-Pacific Intellectual Property Norms: Implications for India, 22(5) The Journal of World Intellectual Property 313-348 (2019).

Akinori Tomohar, Migrant and Business Network Effects on Intellectual Property Trade: Evidence from Japan, 62 ECONOMIC ANALYSIS AND POLICY 131-139 (2019).

C. Bradford Biddle (Ed.), Patent Remedies and Complex Products: Towards a Global Consensus (2019).

\section{$9 \quad$ Environmental Law}

Naeem Abas et al., Cooperative Control of Regional Transboundary Air Pollutants, 8(1) Environmental Systems Research 1-14 (2019).

Myanna Dellinger, Trophy Hunting Under the Precautionary Principle of Law, ANIMAL LAW 21 (2019).

Nikolaos Giannpoulos, Global Environmental Regulation of Offshore Energy Production; Searching for Legal Standards in Ocean Governance, 28(3) REVIEW OF EUROPEAN, Comparative \& International Environmental LaW 289-303 (2019).

Dileep Kumar et al., From Precautionary Principle to Nationwide Ban on Endosulfan in India, 4(2) Business AND Human Rights Journal 343-49 (2019).

Tek Jung Mahat et al., Climate Finance and Green Growth:Reconsidering Climate-Related Institutions, Investments, and Priorities in Nepal, 31(1) ENVIronMENTAL SCIENCES Europe 1-13 (2019).

Benoit Mayer, Environmental Assessments in the Context of Climate Change: The Role of the UN Economic Commission for Europe, 28(1) PL REVIEW of EUROPEAN, COMPARATIVE \& InTERNATIONAL ENVIRONMENTAL LAW 82-93 (2019).

Mostafa Mahmud Naser, Climate Change, Migration and Human Rights in Bangladesh: Perspectives on Governance, 6o(2) Asia PACIFIC ViewPoint 175-19o (2019).

Markus G Puder, The Paris Climate Agreement and Bederman's Six Myths About International Law and International Legal Practice, 52(2) THE INTE RNATIONAL LAWYER 233-64 (2019). 
Daniel F. Robinson et al. (Eds.), Protecting Traditional Knowledge: The WiPO Intergovernmental Committee on Intellectual Property and Genetic Resources, Traditional Knowledge and Folklore (2019).

P.K. Sarker et al., Regional Economic Regimes and The Environment: Stronger Institutional Design is Weakening Environmental Policy Capacity of the South Asian Association for Regional Cooperation, 19(1) International ENVIronmental Agreements: Politics, LaW And Economics 19-52 (2019).

Arie Trouwborst, Global Large Herbivore Conservation and International Law, 28(14) Biodive RSity AND Conservation 3891-3914 (2019).

Amiel Ian Valdez, Beyond the Arbitral Ruling: A Transboundary Environmental Impact Assessment in the South China Sea, 9(2) Asian Journal of International Law 251-274 (2019).

\section{Human Rights}

N.K. Agyeman \& A. Momodu, Universal Human Rights Versus Cultural Relativism: The Meeting Role of Constitutional Rights 12(1) African Journal of LEGAL Studies 23-46 (2019).

Solnara Aktar, Transnational Feminism and Women's Activism: Strategies for Engagement and Empowerment in Bangladesh, 25(2) Asian Journal of WoMEN STUdiEs 285-294 (2019).

Samantha Bradley, The Case for Transformative Reparations for Conflict-Related Sexual Violence in Rakhine State at the ASEAN Intergovernmental Commission on Human Rights, 20(2) Asia Pacific Journal on Human Rights and the Law 181-226 (2019).

Alan Brody, Development Support Communication in Practice: Towards Realizing Child Rights through UNICEF, 29(2) Asia PACIFIC MEdia EduCAToR 89-105 (2019).

Zachary Browning, A Comparative Analysis: Legal and Historical Analysis of Protecting Indigenous Cultural Rights Involving Land Disputes in Japan, New Zealand and Hawaii, 28(1) Pacific Rim LaW and Policy Journal 207-242 (2019).

Yu-Je Chen, China's Challenge to The International Human Rights Regime, 51(4) NEw York University Journal of International LaW \& Politics 1179 (2019).

Srisombat Chokprajakchat, Women Prisoners in North-Eastern Thailand: How Well Do They Meet International Human Rights Standards?, 8(4) INTE R NATI IONAL JOU RNAL For Crime, Justice and Social Democracy 123-136 (2019).

Jerome A. Cohen et. al., Taiwan and International Human Rights: A StORY OF TRANSFORMATION (2019). 
Ross Holder, On the Intersectionality of Religious and Racial Discrimination: A Case Study on the Applicability of ICERD with Respect to China's Uyghur Muslim Minority, 2019(1) Religion and Human Rights 1-30 (2019).

Carolyn E. Holmes, Conventions, Courts, and Communities: Gender Equity, CEDAW and Religious Personal Law in India, 54(7) Journal of Asian ANd African Studies (LEIDEN) 965-979 (2019).

Katharina Holzinger et al., The Constitutionalization of Indigenous Group Rights, Traditional Political Institutions, and Customary Law, 52(12) Comparative PolitiCal STUdies 1775-809 (2019).

Lily Johnson, Commercial Surrogacy is the Sale of Children? An Argument that Commercial Surrogacy does not Violate International Treaties, 19(1) JoURNAL OF SERVICES RESEARCH, 701-726 (2019).

M.Y.A. Kadir, Defining 'People' and 'Indigenous People' in International Human Rights Law and Its Application in Indonesia 26(3) INTERNATIONAL JOURNAL ON MINORITY AND Group Rights 373-408 (2019).

Mya Kadir \& A. Murray, Resource Nationalism in the Law and Policies of Indonesia: A Contest of State, Foreign Investors, and Indigenous Peoples, 9(2) As IAN JournaL of INTERNATIONAL LAW 298-333 (2019).

Gary Lilienthal et al., The Treatment of Chinese Customary Law in British Colonial Hong Kong, 45(4) Commonwealth LaW Bulletin 636-59 (2019).

Siyu Liu et al., The Death Penalty for Foreign Drug Offenders in China: Legal Protection and Equal Treatment, 25(4) European Journal on Criminal Policy and RESEARCH 427-428 (2019).

Jane McPherson et al., Translating Human Rights: Creating Culturally-specific Human Rights Measures for Social Work in Spain, Taiwan and the United States 6(2) INTE RNATIONAL Social Work: SAge Journals 944-949 (2019).

Uche T. Okpara et al., Gender and Land Degradation Neutrality: A Cross-country Analysis to Support More Equitable Practices, 30(11) LAND Degradation AND DevelopMENT 1368-78 (2019).

Martin Ramsted, Prospects of Pluralism in Indonesia Gauges from Legal Anthropological Perspective, 47(3) Asian Journal of Social Science 309-339 (2019).

Schlund et al. (Eds.), The Subjects of Human Rights: Crises, ViolaTIONS, AND Asian/AMERICAN CRITIQUe (2019).

Shobha Raghuram, Inequalities, Caste and Social Exclusion: Dalit Women's Citizenship, 62(1) Development: Palgrave Macmillan 66o-686 (2019).

Andrew Francis Tan \& Zheng Mu, Racial Evolution: Understanding the Resurgence of Ethnic Minority Identity in Modern China, 38(5) Population ReSEARCH AND Policy Review 733-769 (2019). 
Aekje Teeuwen, Juvenile Defendants' Right to be Tried Within a Reasonable Time in Cambodia: An International Human Rights Analysis, 19(1) Youth Justice: SAge Journals 42-62 (2019).

Woldemariam et al., Forced Human Displacement, the Third World and International Law: A TWAIL Perspective, 2O(1) Melbourne Journal of International LAW 248-76 (2019).

M.A. Young et al., Studying Country-Specific Engagements with the International Court of Justice, 10(4) Journal of International Dispute Settlement 582-598 (2019).

Gina Zheng, Reconciling Rights-Based Discourse with Pacific Culture and Way-of-Life: Re-Defining Our Understanding of Rights, 44(3) Alte Rnative Law Journal 24349 (2019).

\section{$11 \quad$ Migration and Refugees}

Zahid Shahab Ahmed, Managing the Refugee Crisis in South Asia: The Role of SAARC, 28(2) Asian And Pacific Migration Journal 210-219 (2019).

G.S. Goodwin-Gill, The Global Compacts and the Future of Refugee and Migrant Protection in the Asia Pacific Region, 30(4) International Journal of REFUge LaW 674-683 (2019).

Konrad Kalicki, Japan's Liberal-Democratic Paradox of Refugee Admission, 78(2) THE Journal of Asian Studies 355-378 (2019).

Kirsten McConnachie, Securitization and Community Based Protection Among Chinese Refugees in Kuala Lumpur, 28(2) Social ANd Legal Studies: SAge Journals 158-178 (2019).

Antje Missbach, Asylum Seekers' and Refugees' Decision-Making in Transit in Indonesia, 175(4) Journals of the Humanities and Social Sciences of South-East Asia 419-445 (2019).

Atin Prabandari \& Yunizar Adiputera, Alternative Paths to Refugee and Asylum Seeker Protection in Malaysia and Indonesia, 28(2) AsIAN AND PACIFIC MIGRATION JOURNAL 132-154 (2019).

Anasuya Syam, Patchwork of Archaic Regulations and Policies in India: A Breeding Ground for Discriminatory Practice Against Refugees, 51(4) NEW YoRK UNIVE RS ITY Journal of International LaW and Politics 1377-1390 (2019).

Tamara Tubakovix, The Failure of Regional Refugee Protection and Responsibility Sharing: Policy Neglect in the EU and ASEAN, 28(2) Asian AND PACIFIC Migration JOURNAL 183-2OO (2019). 


\section{International Humanitarian Law, Criminal Law and Transnational Crime}

Sukhshant Atti and Bonnie Arquilla, International Humanitarian Law and Review of Recurrent Violations Including Chemical Weapons Use, 34(1) Prehospital AND Disaster Medicine s32-s32 (2019).

Dailey J Birkett, Twenty Years of the Rome Statute of the International Criminal Court: Appraising the State of the National Implementing Legislation in Asia, 18(2) CHINESE Journal OF InTERNATIONAL LAW 353-392 (2019).

Marco Bocchese, After Ratification:Predicting State Compliance with ICC Treaty Obligations, 19(4) International Criminal LaW Review 635-668 (2019).

Jonathan Broder, U.S.-Iran Relations: Is a Military Conflict Inevitable?, 29(41) THE CQ ReSEARCHER 1-58 (2019).

Bina Burgess \& John Braithwaite, Cascades of Violence: War, Crime and Peacebuilding Across South Asia, 53(3) Law \& Society Review 935-938 (2019).

Ioannis Chapsos \& Steve Hamilton, Illegal Fishing and Fisheries Crime as a Transnational Organized Crime in Indonesia, 22(3) Trends in Organized Crime 255-273 (2019).

Isabelle Desportes, Getting Relief to Marginalized Minorities: The Response to Cyclone Komen in 2015 in Myanmar, 4(1) Journal of International Humanitarian ACTION 1-16 (2019).

R. Goehrung, Evaluating the Criminal Justice Approach to Human Trafficking in Taiwan, 7(1) Journal of Human TrafFicking 53-68 (2019).

Rohini J. Haar et al., Documentation of Human Rights Abuses Among Rohingya Refugees from Myanmar, 13(1) CONFLict AND HEALTh 42-42 (2019).

Frank Jacob (Ed.), Genocide and Mass Violence in Asia (2019).

Kevin D. Lam, Asian American Youth Violence as Genocide: A Critical Appraisal and Its Pedagogical Significance, 52(2-3) EQUity \& EXCELLENCE IN EdUCATION 255-70 (2019).

Ronan Lee, Myanmar's Citizenship Law as State Crime: A Case for the International Criminal Court, 8(2) State Crime Journal 241-279 (2019).

Adrian A. Lopez, Transnational Links in Rhino Poaching and the Black-market Price of Rhino Horns, 63(1) The Australian Journal of Agricultural and RESOURCE ECONOMICS 95-115 (2019).

G. Mantella, The Protagonism of the USSR and Socialist States in the Revision of International Humanitarian Law, 2 Journals of THE History of INTERNATIONAL LAW 181-211 (2019). 
Michael McKenzie, Securitizing Transnational Crime: The Political Drivers of Police Cooperation Between Australia and Indonesia, 29(3) Policing ANd Society: An International Journal of Research And Policy 338-348 (2019).

Shannu Narayan, Anti-Money Laundering Law in India: A Glocalization Model, 40(3) Statute Law Review 224-235 (2019).

Sergey Sayapin, The General Principles of International Criminal Law in the Criminal Code of the Republic of Kazakhstan, 9(1) Asian Journal of InTERnATIONAL LAW 1-9 (2019).

Prabhakar Singh, Of International Law, Semi-colonial Thailand and Imperial Ghosts, 9(1) Asian Journal of International LaW 46-74 (2019).

Raghavi Viswanath, Elevating Cultural Rights Using International Criminal Law-The Asian Story, 11(1) Asian Journal of International LaW 1-12 (2019).

Sandra Wilson, War Crimes Trials and the Politics of Justice: The Case of Kinoshita Eiichi, 92(257) Historical Research (2019).

\section{Law of the Sea}

Sophie Gambardella, The Stormy Emergence of Geoengineering in the International Law of the Sea,13(2) Carbon \& Climate LaW Review 122-129 (2019).

Michael Sheng-ti Gau, The Interpretation of Article 121(3) of UNCLOS by the Tribunal for the South China Sea Arbitration: A Critique, 5O(1) OCEAN Development AND InTERNATIONAL LAW 49-69 (2019).

Martijn Hoogeland, Case Note: The South China Sea Dispute and the Role of UNCLOS in the Settlement of the Dispute, Quebec Journal of International LaW 93-116 (2019).

Mark Hoskin, Have Great Britain and Other Nations Previously Taken a Stance Concerning the Islands in the South China Sea?, 11(2) Australian Journal of MARitime AND OCEAN AfFairs 132-145 (2019).

Danielle Kroon, The End of Freedom of the Seas?: Grotius, Law of the Sea, and Island Building, 52(2) THe International LAWYer 299-325 (2019).

Zhen Lin, Jurisdiction Over Underwater Cultural Heritage in the EEZ and on the Continental Shelf: A Perspective from the Practice of States Bordering the South China Sea, 5o(2-3) Ocean Development and International LaW 170-189 (2019).

Deyi Ma, Obligation to Exchange Views under Article 283 of the United Nations Convention on the Law of the Sea: An Empirical Approach for Improvement, 12(2) JOURNAL of East Asia And International LaW 305-320 (2019).

Mark Bryan Manantan, Pivot Toward China: A Critical Analysis of the Philippines' Policy Shift on the South China Sea Disputes, 11(4) Asian Politics AND Policy 643-662 (2019). 
Napang et al., Contesting Views of the Philippines and China over the Nine-Dash Line in the South China Sea, 12(1) Journal of EAST Asia AND INTERNATIONAL LAW 180-92 (2019).

Fayokemi Ayodeji Olorundami, Should the Diaoyu/Senkaku Islands Be Classified as Islands or Rocks? An Examination in Light of the South China Sea Arbitration Award, 34(2) The International Journal Of Marine and Coastal Law 325-349 (2019).

Hao Duy Phan, International Courts and State Compliance: An Investigation of the Law of the Sea Cases, 5O(1) OCEAn Development and International LaW 70-9O (2019).

Hui Gao Qi, Joint Development in the South China Sea: China's Incentive and Policy Choices, 8(2) Journal of Contemporary East Asia Studies 220-239 (2019). Yoshifumi Tanaka, Marine Spaces Under National Jurisdiction I: Territorial Sovereignty, The International LAW of the SeA 94-144 (3 ed. 2019).

Yong Wang, Reasonable Restrictions on Freedom of High Seas by 'Marine Protected Areas on the High Seas': An Empirical Research, 12(2) JoU RNAL OF EAST ASIA AND INTERNATIONAL LAW 245-268 (2019).

\section{Maritime Law}

P. Amarsinghe \& S. Rajhans, Law of the Sea - Islamic Law of the Sea: Freedom of Navigation and Passage Rights in Islamic Thought by Hassan S. KHALILIEH, n(1) AsIAN Journal of InTERNATIONAL LAW 219-220 (2019).

Anmolam Farheen Ahmad, Separation of the Chagos Archipelago from Mauritius, EcoNomic ANd Political Weekly (2019).

Carla P. Freeman, An Uncommon Approach to the Global Commons: Interpreting China's Divergent Positions on Maritime and Outer Space Governance, 241 THE CHINA QUARTERLY 1-21 (2019).

Youna Lyons et al., Moving from MPAs to Area-Based Management Measures in the South ChinaSea 35(2) The International Journal of MARine And CoAstal LAW 201-21 (2019).

Paul Rae, Archipelagic Performance: Scenes from Maritime Southeast Asia, 71(4) THEAtre Journal 455-473 (2019).

M. Andrew Song et al., 'Blue Boats' and 'Reef Robbers': A New Maritime Security Threat for the Asia Pacific?, 6o(3) Asia PAcific Viewpoint 310-324 (2019).

Dirk J Steenberhen et al., Governance Interactions in Small-Scale Fisheries Market Chains: Examples from the Asia-Pacific, 2O(4) FISH AND FISHERIES 697-714 (2019). Rebecca Strating, Maritime Disputes, Sovereignty and the Rules-Based Order in East Asia, 65(3) The Australian Journal of Politics and History 449-465 (2019). 
MA Xinmin, China's Arctic Policy on the Basis of International Law: Identification, Goals, Principles and Positions, 100 Elsevier Journal of Marine Policy 256-276 (2019).

Constantinos Yiallourides, Maritime Disputes and International LaW: Disputes Waters and Seabed Resources in Asia and Europe (2019).

\section{Watercourses}

Meir Alkon et al., Water Security Implications of Coal-Fired Power Plants Financed Through China's Belt and Road Initiative, 132 ENE RGY POLICY 1101-1109 (2019).

T. Amjath-Babu et al., Integrated Modelling of the Impacts of Hydropower Projects on the Water-Food-Energy Nexus in a Transboundary Himalayan River Basin, 239 ELSEVIE R Journal of Applied Energy 494-503 (2019).

Hyeyeong Choe \& James H. Thorne, Climate Exposure of East Asian Temperate Forest Suggests Transboundary Climate Adaptation Strategies are Neeses, 156(1) CLIMATE CHANGe 51-67 (2019).

Sojeong Lee \& S. Mitchell, Energy Resources and the Risk of Conflict in Shared River Basins, 56(3) Climate Journal of Peace Research 336-351 (2019).

David MacNabb, Global Pathways to Water Sustainability (2019).

Tasleem Malik, Pak-Afghan Water Issue: A Case for Benefit Sharing, 16(1) PLuto JourNALS 77-98 (2019).

Jianan Qin et al., Asymmetric Bargaining Model for Water Resource Allocation over Transboundary Rivers, 16(10) InTERnAtional Journal of ENVIRONMENTAL Research and Public Health 1733 (2019).

Iain Watson \& Juliette Schwank, Water Security, Riparian Identity and Korean Nation Branding in the Mekong Subregion, 34(2) PACIFIC Focus 153-182 (2019).

16

\section{Cyber Law and Security}

Jungbae An \& Tae Yoo, Internet Governance Regimes by Epistemic Community: Formation and Diffusion in Asia, 25(1) Global Governances: A Review of MultilaterALISM AND INTERNATIONAL ORgANiZATIONS 123-148 (2019).

Walter C. Clements, Cyber and Other Powers in Asia, 43(3) Asian Perspective: John HOPKINS 585-592 (2019).

Leif Eric Easely \& Sea Young Kim, New North-Southeast Asia Security Links: Defending, Recentering, and Extending Regional Order, 65(3) The Australian Journal of Politics AND History 377-394 (2019). 
Yang Feng, The Future of China's Personal Data Protection Law: Challenges and Prospects, 27(1) Asia Pacific Law Journal 62-82 (2019).

Tianru Guan, Who are the Influential in China's Cyberspace and What Do They Say About Issue of Sino-Japanese Relations?, 19(3) JournaL of EASt Asian Studies 383396 (2019).

Zhixiong Huang \& Yao Hui Ying, The Application of the Principle of Distinction in the Cyber Context: A Chinese Perspective, 102(193) International Review of THe Red Cross 335-365 (2019).

Rita Ismailova et al., Cybercrime Risk Awareness Rate Among Students in Central Asia: A Comparative Study in Kyrgyzstan and Kazakhstan, 28(4-5) Information SECURITY JOURNAL 127-135 (2019).

Nori Katagiri, From Cyber Denial to Cyber Punishment: What Keeps Japanese Warriors from Active Defense Operations? AsIAN SECURITY 1-18 (2019).

Hai Thanh Luong et al. Understanding Cybercrimes in Vietnam: From Leading-Point Provisions to Legislative System and Law Enforcement, 13(2) INTE RNATIONAL JOU RNAL of Cyber Criminology 29o-308 (2019).

Hai Thanh Luong et al., Understanding Cyber Crimes in Vietnam: From Leading-Point Provisions to Legislative System and Law Enforcement, 13(2) INTERNATIONAL JOURNal of Cyber Criminology 29o-308 (2019).

Hitoshi Nasu et al., The Legal Authority of ASEAN as a Security InstiTUTION (2019).

Elvin Ong, Online Repression and Self-Censorship: Evidence from Southeast Asia, 56(1) Government Opposition: An International Journal of Comparative Politics 1-22 (2019).

Muhammad Shaban Rafi, Cyberbullying in Pakistan: Positioning the Aggressor, Victim and Bystander, 34(3) Pakistan Journal of Psychological Research 6o1620 (2019).

Asif Salim et al., Contemporary Digital Age and Dynamics of E-jihad in the Muslim World: Case Study of Pakistan, 11(4) PAKIStan Journal of Criminology 102-114 (2019). Ryan Shandler \& Daphna Canetti, A Reality of Vulnerability and Dependence: Internet Access as a Human Right, 52(1) IsRAEL LAW REVIEW 77-98 (2019).

\section{$17 \quad$ Air and Space \& Nuclear}

Gawdat Bahgat, Iran's Ballistic-Missile and Space Program: An Assessment, 26(1) MIDDLE EAST Policy 31-48 (2019).

Rajesh Basrur, India and China: A Managed Nuclear Rivalry? 42(3) TH E WASHIN G ton QUARTERLY 151-170 (2019). 
Noriko Behling et al., Regulating Japan's Nuclear Power Industry to Achieve ZeroAccidents, 127 Energy Policy 3o8-19 (2019).

Mark S. Bell, Nuclear Opportunism: A Theory of How States Use Nuclear Weapons in International Politics, 42(1) Journal of Strategic Studies 3-28 (2019).

Xiaowen Ding et al., Policies on Water Resources Assessment of Coastal Nuclear Power Plants in China, 128 ENe Rgy Policy 170-78 (2019).

David F. Von Hippel \& Peter Hayes, Regional Cooperation for Nuclear Spent Fuel Management in East Asia: Costs, Benefits and Challenges - Part II, 2(1) JoURNAL FOR Peace and Nuclear Disarmament 319-35 (2019).

Inwook Kim \& Jung-Chul Lee, Sanctions for Nuclear Inhibition: Comparing Sanction Conditions Between Iran and North Korea, 43(1) Asian Perspective 95-122 (2019). Mingyan Nie, Asian Space Cooperation and Asia Pacific Space Cooperation Organization: An Appraisal of Critical Legal Challenges in the Belt and Road Space Initiative Context, 47 Elsevier Journal of Space Policy 224-232 (2019).

Tom Sauer, The Role of Informal International Organizations in Resolving the Iranian Nuclear Crisis (2003-15), 57(5) Journal of Common Market Studies 939-955 (2019).

Tatsujiro Suzuki \& S. Hirose, Report of Panel on Peace and Security of Northeast Asia (PSNA) 2018, 2(1) Journal FOr PEACE ANd NuClear Disarmament 378-386 (2019).

Yongliang Yan, Maintaining Long-Term Sustainability of Outer Space Activities: Creation of Regulatory Framework to Guide the Asia-Pacific Space Cooperation Organization and Selected Legal Issues, 47 Elsevier Journal of Space Policy 51-62 (2019).

Fumihiko Yoshida \& Tatsujiro Suzuki, The State of Nuclear Weapons in 2019: Conversations with Experts at the Carnegie International Nuclear Policy Conference, 2(2) Journal of Peace and Nuclear Disarmament 612-26 (2019).

\section{Miscellaneous}

G. Ibrahim Aoude, Conflict Over Oil and Gas in the Mediterranean: Israeli Expansionism in Lebanon, 41(1) Arab Studies Quarterly: Pluto Journals 95-110 (2019).

Eugene Gholz, Defensive Defense: A Better Way to Protect US Allies in Asia, 42(4) The WASHINGTON QUARTERLY 171-189 (2019).

Kyoko Hatakeyama, A Middle Power's Roles in Shaping East Asian Security Order: Analysis of Japan's Engagement from a Normative Perspective, 65(23) THe Australian Journal of Politics ANd History 466-481 (2019).

Zia Mian et al., Nuclear Submarines in South Asia: New Risks and Dangers, 2(1) JouRnal for Peace and Nuclear Disarmament 184-202 (2019). 
T.J. Pempel, Right Target; Wrong Tactics: The Trump Administration Upends East Asian Order, 32(6) The Pacific Review 996-1018 (2019).

Huong Le Thu, China's Dual Strategy of Coercion and Inducement Towards ASEAN, 32(1) The Pacific Review 20-36 (2019).

Ketian Zhang, Cautious Bully: Reputation, Resolve, and Beijing's Use of Coercion in the South China Sea, 44(1) International Security 117-159 (2019).

Qichao Zhu \& Kun Long, How Will Artificial Intelligence Impact Sino-US Relations? 1(1) China International Strategy Review 139-151 (2019).

Wan Pun Lung, International Law before the Courts of the Hong Kong Special Administrative Region of the People's Republic of China - Twenty Years On, 9(1) AsIAN JOURNAL OF INTERNATIONAL LAW 1O-19 (2019). 